\title{
THE CYCLICALITY OF FISCAL POLICY IN SOUTH ASIA
}

The paper empirically analyses the role of macroeconomic, political and institutional variables in determining cyclical patterns of government revenues, expenditures and fiscal balance in South Asian Countries (SACs). Panel regression analysis is conducted for the period 1980 to 2013. The findings support existing literature about developing countries demonstrating that fiscal policies are strongly procyclical in SACs and there is significant evidence of persistence. Revenues have decreased and expenditures have increased with output cycle which has deteriorated the fiscal balance. This indicates that fiscal balance is procyclical with output cycle in SACs and this procyclicality increases during good times. The results suggest that SACs can conduct counter cyclical fiscal policies if they stabilize output, control inflation and structural shocks, have deep financial markets, high financial openness, have few veto players in the political procedures and have stronger institutions. These results are robust to alternative measures of output cycle and model specifications.

Keywords: Fiscal Policy, Cyclicality, Volatility

JEL Classifications: C33, E32, E62

DOI: $10.15611 /$ aoe.2015.1.01

\section{INTRODUCTION}

Fiscal policy is the use of government revenues and expenditures to affect the economy, specifically aggregate demand, to stimulate economic growth, to attain price stability and full employment level. Governments also use fiscal policies to overcome market failures and to redistribute resources optimally. Cyclical fluctuations of an economy cause cyclical fluctuations of tax revenues and government spending, thereby altering the fiscal policy situation. Thus, the cyclicality of fiscal policy has become an important issue because it shows the constraints which a government faces in formulating its policies. Kaminsky et al. (2004) have documented three types of fiscal policy by assessing the direction of co-movement between fiscal policy

\footnotetext{
* Shanghai University of Finance and Economics (SHUFE), P.R. China, COMSATS Institute of Information Technology (CIIT), Islamabad, Pakistan

${ }^{* *}$ Shanghai University of Finance and Economics (SHUFE), P.R. China
} 
instruments, i.e. tax rates and government spending, and economic cycles. These fiscal policies are (i) acyclical fiscal policy; (ii) counter cyclical fiscal policy; and (iii) procyclical fiscal policy. Fiscal policy is said to be acyclical when spending and tax rates remain constant over the economic cycle; a pattern that will neither reinforce nor stabilize the business cycle. Counter cyclical fiscal policy will occur when government lowers (raises) spending and raises (lowers) tax rates in good (bad) times, because, for example, a reduction of spending and raising of tax rates tends to stabilize the business cycle. In turn, in procyclical fiscal policy, government raises (lowers) spending and lowers (raises) tax rates in good (bad) times. In this context, a counter cyclical fiscal policy is defined as running fiscal deficits in bad times and a surplus in good times, whereas a procyclical fiscal policy is defined as running fiscal deficits or a surplus lower than what would otherwise have been achieved given the cycle of the economy, during good times.

Counter cyclical fiscal policies occur if a government follows a Keynesian stabilization policy. According to Keynes, a fiscal policy should act as a stabilizing tool and therefore it should be counter cyclical. In bad times the government should increase its spending and should reduce taxes in order to bring the economy out of recession. In other words, a counter cyclical fiscal policy occurs due to automatic stabilizers. For instance, government increases unemployment allowance and other welfare spending during an economic downturn and reduces the tax burden at the same time. Thus countries which are unable to conduct welfare spending during recessions they follow procyclical fiscal policies. These countries, in fact, face severe credit constraints which prevent them from increasing welfare expenditure during recessions. Thus, if a government accumulates lower tax revenue during a recession and consequently reduces its expenditure to avoid fiscal deficit, it is mainly because this government is facing credit constraints to finance the deficit (Gavin and Perotti, 1997; Catao and Sutton, 2002). It is, therefore, argued that poor countries run procyclical fiscal policies and rich countries have counter cyclical fiscal policies.

Empirical literature has also shown that developed countries conduct either acyclical or counter cyclical fiscal policies (Gali, 1994; Fiorito and Kollintzas, 1994; Fiorito, 1997), while in developing countries fiscal policy is generally procyclical. Gavin and Perotti (1997) were the first to show that that fiscal policy is procyclical in Latin American countries. After that Stein et al. (1999) have also shown that fiscal policy in Latin America is procyclical. Talvi and Vegh (2005) claim that procyclical fiscal policy seemed to be the rule in developing countries. Using time series data for Irish fiscal policy, Lane (1998) suggest that fiscal procyclicality holds even 
in a single country. To be brief, empirics suggest that procyclicality has become part of fiscal policies in developing countries (Braun, 2001; Kaminsky et al. 2004; Alesina et al. 2008; Manasse, 2006; Ilzetzki and Vegh, 2008; Lane, 2003).

Several explanations have been put forward for procyclical fiscal policies in developing countries. The first one is the financial market imperfections argument, also known as the structural argument. According to this argument limited integration (or access) to domestic and external financial markets may reduce the ability of government to adopt an expansionary fiscal policy in bad times when governments have no option but to reduce expenditure or increase taxation (Gavin and Perotti, 1997; Caballero and Krishnamurthy, 2004). The second is the quality of institutions also known as institutional arguments. According to this argument, countries follow procyclical fiscal policies because their (political) institutions are weak with high corruption levels. Alesina et al. (2008) put forward that procyclical fiscal policy may be the result of corrupt democratic institutions where influential groups (voters) lead to political distortions. Consequently during good times, the tax rate decreases and spending increases, which results in budget deficit (Tornell and Lane, 1999; Talvi and Vegh, 2005). This is called the voracity effect and common pool problem. Empirically, Calderon and Schmidt-Hebbel (2008) and Frankel et al. (2011) have shown that institutional factors play a dominant role in the procyclicality of fiscal policy compared to financial market imperfections.

Theoretically, both neoclassical and New Keynesian models have revealed that procyclical fiscal policy is not optimal. Fiscal policy in neoclassical models is optimal when it is either acyclical (Barro, 1979) or counter cyclical (Baxter and King, 1993). In turn, in the New Keynesian framework, the optimal policy is basically counter cyclical due to the presence of price rigidity or sticky wages (Christiano et al., 2011). Since procyclical fiscal policy is not optimal, there are great concerns over procyclical fiscal policies, which can exacerbate economic fluctuations, hamper growth, and have long-term welfare implications (IMF, 2005). Furthermore, if expansionary fiscal policy in good times is not fully offset in bad times, then it may result in large fiscal deficits and a build-up of debt which ultimately put pressure on interest rates. Moreover, by adding aggregate demand, high deficits can increase inflation and/or adversely affect the balance of payments. All of which hampers the ability of government to control unexpected fiscal shocks and to run a counter cyclical fiscal policy. Thus, understanding the cyclicality of the fiscal policies is very important as it may help to design stabilization and adjustment programmes. 
Although some research has been conducted to explore the factors causing the fiscal cyclicality, however this research is mainly focused on developed and emerging countries and pays little attention to the developing countries of South Asia. In SACs, Hussain and Siddiqi (2013) have analyzed the cyclicality of government expenditures in six SACs using data from 1980 to 2010. They conclude that fiscal policy is procyclical in these countries and that weak political system and poor institutions do not contribute to the procyclicality of government spending as these variables are insignificant. They suggest that to bring stability into economic growth in SACs, counter cyclical fiscal policies should be adopted. The main limitation of this study is that it considers only the cyclicality of government expenditure and ignores government revenue and the fiscal balance. The main objective of this paper is to discuss the cyclical proprieties of fiscal policy in South Asia and to explore the factors responsible for fiscal cyclicality in South Asian countries (SACs). Special focus will be given to the political and institutional variables in determining the fiscal cyclicality.

The paper is organized as follows. Section 2 presents the theoretical framework. Section 3 discusses data sources and econometric issues. Section 4 provides the estimated results. The final section presents conclusions.

\section{THEORETICAL FRAMEWORK}

\subsection{Econometric Models}

The study will assess the cyclical pattern of fiscal balance by examining the cyclical behaviour of government revenue and expenditure. Figure 1 presents the schematic representation of our proposed framework.

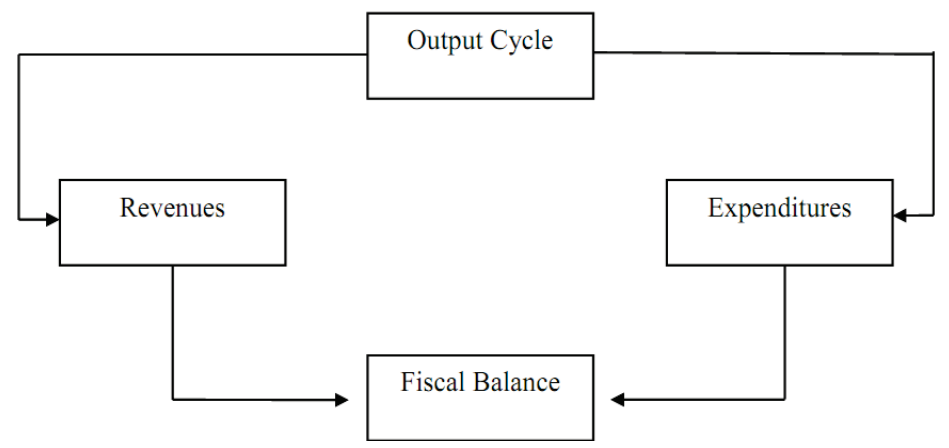

Figure 1. Schematic Representation of the Analytical Framework 


\subsubsection{Cyclicality of Revenues}

To observe the cyclicality of government revenues, we will estimate the following regression equation: ${ }^{1}$

$$
f_{i, t}^{r}=\lambda+\alpha y_{i, t}+\mathbf{A}^{\prime} \mathbf{X}_{\mathbf{i}, \mathbf{t}}+\varsigma_{i}+\phi_{t}+\mu_{i, t}
$$

Where $f_{i, t}^{r}$ is a fiscal policy indicator which is revenue to GDP ratio, $y$ is real GDP, $\mathbf{X}$ is a matrix of independent variables, $\mathbf{A}$ is the matrix of parameters of the control variables, $\varsigma_{i}$ and $\phi_{t}$ refer to country and time effects, and $\mu_{i, t}$ is the stochastic error term. Based on different control variables, we will estimate three different versions of equation (1):

Model $1 \quad f_{i, t}^{r}=\lambda+\alpha_{1} y_{i, t}+\alpha_{2} t_{t o t} t_{i, t-1}+\alpha_{3} d_{i, t}+\varsigma_{i}+\phi_{t}+\mu_{i, t}$

Model 2

$$
\begin{aligned}
f_{i, t}^{r}=\lambda+ & \alpha_{1} y_{i, t}+\alpha_{2} \text { tot }_{i, t-1}+\alpha_{3} \pi_{i, t} \\
& +\alpha_{4} f d_{i, t}+\alpha_{5} f o_{i, t}+\alpha_{6} d_{i, t}+\varsigma_{i}+\eta_{t}+\mu_{i, t}
\end{aligned}
$$

Model $3 f_{i, t}^{r}=\lambda+\alpha_{1} y_{i, t}+\alpha_{2}$ tot $_{i, t-1}+\alpha_{3} \pi_{i, t}+\alpha_{4} f d_{i, t}$

$$
+\alpha_{5} f o_{i, t}+\alpha_{6} d c_{i, t}+\alpha_{7} i q_{i, t}+\alpha_{8} d_{i, t}+\varsigma_{i}+\eta_{t}+\mu_{i, t}
$$

In Model 1 we have included only two control variables, that is (lagged) terms of trade (tot) shocks, and a structural dummy $(d)$. Model 2 is an augmented version of Model 1 in which three more control variables are included, which are basically macroeconomic (and financial) variables. These variables are inflation $(\pi)$, financial depth $(f d)$, and financial openness $(f o)$. Finally, by including the political and institutional variables, we get Model 3. In Model 3 the democracy variable $(d c)$ is included to take into account the effect of the political regime on the fiscal variable, while an institutional quality $(i q)$ variable is included to capture the effect of bureaucratic quality on fiscal cyclicality.

\footnotetext{
1 Previously, Hercowitz and Strawczynski (2004), Alesina et al. (2008), Calderon and Schmidt-Hebbel (2008) and Endegnanew (2013) used such type of models.
} 


\subsubsection{Cyclicality of Expenditures}

We will also explore the cyclical behaviour of government expenditures. If we measure fiscal variable with government expenditures, our model will become:

$$
f_{i, t}^{e}=\gamma+\beta y_{i, t}+\mathbf{B}^{\prime} \mathbf{X}_{\mathbf{i}, \mathbf{t}}+\xi_{i}+\varphi_{t}+v_{i, t}
$$

Where $f_{i, t}^{e}$ is a fiscal policy indicator which is expenditure to GDP ratio, $y$ is real GDP, $\mathbf{X}$ is a matrix of independent variables, $\mathbf{B}$ is the matrix of parameters of the control variables, $\xi_{i}$ and $\varphi_{t}$ refer to country and time effects, and $v_{i, t}$ is the stochastic error term. Based on different control variables, we will estimate the following three different versions of equation (2):

Model 1

$$
f_{i, t}^{e}=\gamma+\beta_{1} y_{i, t}+\beta_{2} \text { tot }_{i, t-1}+\beta_{3} d_{i, t}+\xi_{i}+\varphi_{t}+v_{i, t}
$$

Model 2

$$
\begin{aligned}
f_{i, t}^{e}=\gamma+\beta_{1} y_{i, t}+\beta_{2} \text { tot }_{i, t-1}+\beta_{3} \pi_{i, t} \\
+\beta_{4} f d_{i, t}+\beta_{5} f_{i, t}+\beta_{6} d_{i, t}+\xi_{i}+\varphi_{t}+v_{i, t}
\end{aligned}
$$

Model $3 f_{i, t}^{e}=\gamma+\beta_{1} y_{i, t}+\beta_{2}$ tot $_{i, t-1}+\beta_{3} \pi_{i, t}+\beta_{4} f d_{i, t}$

$$
+\beta_{5} f_{i, t}+\beta_{6} d c_{i, t}+\beta_{7} i q_{i, t}+\beta_{8} d_{i, t}+\xi_{i}+\varphi_{t}+v_{i, t}
$$

\subsubsection{Cyclicality of Fiscal Balance}

Finally, we will see the cyclicality of the fiscal balance. Since by definition, fiscal balance is the difference between revenues and expenditures, by subtracting spending equation (2) from revenue equation (1) we can get the fiscal balance equation as follows:

$$
f_{i, t}^{b}=\theta+\rho y_{i, t}+\mathbf{P}^{\prime} \mathbf{X}_{\mathbf{i}, \mathbf{t}}+\zeta_{i}+\psi_{t}+v_{i, t}
$$

where $f_{i, t}^{b}$ is a fiscal policy indicator which is fiscal/budget balance to GDP ratio, $y$ is real GDP, $\mathbf{X}$ is a matrix of independent variables, $\mathbf{P}$ is the matrix of parameters of the control variables, $\zeta_{i}$ and $\psi_{t}$ refer to country and time effects, and $v_{i, t}$ is the stochastic error term. Based on different control variables, we will estimate the following three different versions of equation (3): 
Model 1

$$
f_{i, t}^{b}=\theta+\rho_{1} y_{i, t}+\rho_{2} \text { tot }_{i, t-1}+\rho_{3} d_{i, t}+\zeta_{i}+\psi_{t}+v_{i, t}
$$

Model 2

$$
\begin{aligned}
f_{i, t}^{b}=\theta+\rho_{1} y_{i, t}+\rho_{2} \text { tot }_{i, t-1}+\rho_{3} \pi_{i, t} & \\
& +\rho_{4} f d_{i, t}+\rho_{5} f o_{i, t}+\rho_{6} d_{i, t}+\zeta_{i}+\psi_{t}+v_{i, t}
\end{aligned}
$$

Model $3 f_{i, t}^{b}=\theta+\rho_{1} y_{i, t}+\rho_{2}$ tot $_{i, t-1}+\rho_{3} \pi_{i, t}+\rho_{4} f d_{i, t}$

$$
+\rho_{5} f o_{i, t}+\rho_{6} d c_{i, t}+\rho_{7} i q_{i, t}+\rho_{8} d_{i, t}+\zeta_{i}+\psi_{t}+v_{i, t}
$$

\subsection{Theoretical Justification of the Variables}

\subsubsection{Output Cycle}

Theoretically, various explanations have been put forward to describe the procyclicality behaviour of fiscal variables in developing economies. The most important theoretical argument about the cyclicality of fiscal policy is the 'tax smoothing' hypothesis. According to this hypothesis, taxes should remain constant over the business cycle for a given path of government expenditures and the budget balance should behave in a procyclical manner (Barro, 1979).

\subsubsection{Terms of Trade Shocks}

To see the effect of external shocks on fiscal cyclicality, we take into account the terms of trade index. The external terms of trade shocks are considered as an important source of fiscal instability in developing economies. Any change in export and import prices influence the government fiscal balance by changing the profits of public sector enterprises engaged in exports of goods and services, or via export taxes and import tariffs. An improvement in the terms of trade decreases government social spending by promoting economic activities. In this sense, terms of trade is counter cyclical as it reduces budget deficits. In turn, deterioration in terms of trade decreases economic activities. As a result, government will increase its expenditure to hedge against adverse external shocks. Now government will opt for procyclical fiscal policies. 


\subsubsection{Inflation}

Inflation rate is a fiscal space variable that can affect fiscal cyclicality. In developing countries, fiscal deficits are inflation induced. ${ }^{2}$ Woo (2003) explains that rising inflation increases government expenditures by increasing (nominal) interest payments. Inflation also increases the cost of government investment expenditure and budgetary demand for government transfer payments will also increase. Higher inflation may also decrease (real) tax revenue collections. In this sense high inflation is procyclical as it will deteriorate fiscal balance by increasing expenditures and reducing revenues. However, if income tax is not indexed to inflation, then the negative effects of inflation on fiscal balance can be at least partially offset by the positive effect of bracket creep on income tax revenue. Generally, government expenditures adjust more rapidly than revenues to a change in a price level and in such a way that a procyclical budgetary deficit emerges.

\subsubsection{Financial Depth}

Caballero and Krishnamurthy (2004) postulate that developing countries may follow counter cyclical fiscal policies if they have high financial depth (i.e. their financial system is highly developed). The intuition is that credit expansion generates additional revenues via different channels. First, high credit growth has a positive effect on domestic assets and property prices which in turn increases revenues. Second, high credit growth increases asset market turnover that increases revenue from transaction taxes. Third, if credit expansion redistributes resources from sectors which pay low taxes to sectors which pay high taxes, then government tax revenues will increase. Fourth, credit growth may increase inflation and appreciate the real exchange rate (by increasing the relative price of non-tradables), and since inflation is also a kind of tax, tax revenues will increase as taxes are not fully inflationindexed. To gauge the effect of financial depth on fiscal variables, we will include a financial development variable proxied by domestic credit to private sector (\% of GDP). It is expected that the higher values of financial development (i.e. a more financially developed system) have a counter cyclical effect on fiscal variables.

\footnotetext{
${ }^{2}$ According to the 'fiscal theory of the price level' it is fiscal policy that affects the inflation rate, and not the other way round (Leeper, 1991; Woodford, 1995).The intuition is that for the price level to be stable or to control the inflation rate, government must run a balanced budget or government finances must be sustainable over the course of the business cycle, and there should not be any structural deficits. However, this theory has been criticized by Buiter (1999).
} 


\subsubsection{Financial Openness}

It is argued that developing countries may not follow counter cyclical fiscal policies because they face credit supply constraints (Gavin and Perotti, 1997). Gavin et al. (1996) document that developing countries conduct procyclical fiscal policies because developing countries are financially less open. As a result, these countries are unable to borrow from the world credit market when an adverse shock hits the economy. Even if these countries are somehow able to borrow then they have to pay a very high interest rate. So these countries have to reduce their expenditures. Thus, developing countries are forced to run a procyclical fiscal policy during downturns. In turn, developing countries can borrow easily during upturns to increase their public expenditures (Gavin and Perotti, 1997; Catao and Sutton, 2002). This indicates that capital inflows to developing countries are procyclical, i.e. these countries borrow in good times and repay in bad times (Kaminsky et al. 2004; Alesinaet al. 2008). This procyclical behaviour of capital inflow in developing countries forces these countries to run procyclical fiscal policies. To see the effect of international financial integration on the cyclicality of the fiscal variables we will use the financial openness index developed by Chinn and Ito (2008).

\subsubsection{Democracy}

It is argued that democratic governments are involved in rent seeking activities by servicing special interest groups or by the direct allocation of tax revenues. Furthermore, during expansion, voters demand lower taxes and more public expenditures because they believe that the government will misappropriate resources. To finance high public spending due to rent seeking activities, governments borrow from the domestic and international financial markets but the voters are not able to perceive this as government borrowing (Alesina et al. 2008). Thus a weak and corrupt democratic system and the voters' imperfect information force governments in developing countries to run procyclical fiscal policies. Alesina et al. (2008) claim that democratic governments that control corruption can pursue counter cyclical fiscal policies. To explore the effect of a weak political system on the cyclicality of fiscal variables, we will use polity 2 score from the Polity IV codebook.

\subsubsection{Institutional Quality}

If the legal and political institutional framework is weak, then during upturns powerful groups will compete for a share in fiscal revenue (voracity effect). In the literature this is also known as the common pool problem, 
where powerful groups put pressure on governments to escalate spending when fiscal resources are available. As a result, fiscal spending can grow more proportionally and over-spending occurs instead of saving the income by running a budget surplus (Tornell and Lane, 1999). All this indicates that fiscal balance is procyclical in the presence of weak institutions. In turn, when institutional quality improves, then a more efficient tax collection system and better monitoring expenditure system can improve the fiscal balance. In this regard, an improvement in the rule of law and the efficiency of public sector by decreasing the degree of corruption can improve the budgetary position. We will use the political risk index from the International Country Risk Guide (ICRG) data set in order to take into account the effect of institutional quality on the cyclicality of the fiscal policies. It is argued that governments which have strong institutions are able to run counter cyclical fiscal policies.

\subsubsection{Dummy}

A dummy variable for $9 / 11$ is included in the model. The intuition is that after this event, remittances have increased in SACs and foreign aid especially to Pakistan - also increased as it worked as a front line state

Table 1

Theoretically Expected Effects of Independent Variables on Fiscal Variables

\begin{tabular}{l|c|c|c}
\hline \multicolumn{1}{c|}{ Variables } & Revenues & Expenditures & Fiscal Balance \\
\hline Output Cycle & + & - & + \\
Terms of Trade Shock & $(-)$ & $(+)$ & $(-)$ \\
\multirow{4}{*}{ Inflation } & + & - & + \\
& $(-)$ & $(+)$ & $(-)$ \\
Financial Depth & + & - & + \\
& $(-)$ & $(+)$ & $(-)$ \\
Financial Openness & + & - & + \\
\multirow{2}{*}{ Democracy } & $(-)$ & $(+)$ & $(-)$ \\
& + & - & $(-)$ \\
Institutional Quality & $(-)$ & - & + \\
& + & $(+)$ & $(-)$ \\
Dummy & $(-)$ & - & $(+$ \\
& $(-)$ & - & $(-)$ \\
& + & $(+)$ & $(-)$ \\
\hline
\end{tabular}

Note: Signs within (out) parentheses indicate pro(counter)cyclical effect. 
against terrorism. This increase in remittances has improved the fiscal balance of these countries. So these countries have run counter cyclical policies in the wake of remittances and foreign aid.

Table 1 summarizes the theoretically expected effects of independent variables on fiscal variables.

\section{DATA SOURCE AND ECONOMETRIC ISSUES}

\subsection{Data Source}

Annual data is collected for SACs for the period 1980 to 2013. The South Asian countries included are Bangladesh, Bhutan, India, Maldives, Nepal, Pakistan and Sri Lanka. To examine fiscal cyclicality we will use three fiscal variables: revenues, expenditures and fiscal balance. These variables are expressed as a percentage of GDP. Previously many studies used these variables to assess fiscal cyclicality. For instance, see among others, Fatas and Mihov (2001), Alesina et al. (2008), Badinger (2008), Gavin and Perotti (1997), Manasse (2006) and Kaminsky et al. (2004). Table 2 provides the list of all the variables used in this study along with their data sources.

\section{Table 2}

Measurement of Variables Used in the Analysis

\begin{tabular}{l|l}
\hline \multicolumn{1}{c|}{ Variable } & \multicolumn{1}{c}{ Description and Data Source } \\
\hline \multicolumn{1}{c}{1} & \multicolumn{1}{c}{2} \\
\hline $\begin{array}{l}\text { Dependent Variables } \\
\text { Government } \\
\text { Revenues }\end{array}$ & $\begin{array}{l}\text { Government Revenues (percentage of GDP) } \\
\text { Data Source: Asian Development Bank (ADB) } \\
\text { Government } \\
\text { Expenditures }\end{array}$ \\
Fiscal Balance & $\begin{array}{l}\text { Data Source: Asian Development Bank (ADB) } \\
\text { Fiscal Balance (percentage of GDP) } \\
\text { Data Source: Asian Development Bank (ADB) }\end{array}$ \\
Independent Variables \\
Output Cycle & $\begin{array}{l}\text { Real GDP } \\
\text { Data Source: Penn World Table (PWT); World Development Indicators } \\
\text { (WDI) }\end{array}$ \\
Terms of Trade & $\begin{array}{l}\text { Terms of trade index is export price index divided by import price } \\
\text { index } \\
\text { Data Source: World Development Indicators (WDI); International }\end{array}$ \\
& Financial Statistics (IFS)
\end{tabular}




\begin{tabular}{l|l}
\hline \multicolumn{1}{c|}{} & \multicolumn{1}{c}{2} \\
\hline Inflation & $\begin{array}{l}\text { Growth rate of consumer price index } \\
\text { Data Source: World Development Indicators (WDI); International } \\
\text { Financial Statistics (IFS) } \\
\text { Domestic credit to private sector (percentage of GDP) } \\
\text { Data Source: World Development Indicators (WDI) } \\
\text { The Chinn and Ito (2008) index. This is an index measuring a country's } \\
\text { degree of capital account openness. The index takes on higher values } \\
\text { the more open the country is to cross-border capital transactions. } \\
\text { Polity2 score It is scaled between -10 (full autocracy) and }+10 \\
\text { Openness }\end{array}$ \\
Democracy & $\begin{array}{l}\text { International Country Risk Guide (ICRG) political risk index It is } \\
\text { scaled between 0 and 100. Lower values show higher risk (low quality) } \\
\text { and higher values show lower risk (high quality). } \\
\text { 9/11 dummy, which takes the value of 1 after the event of 9/11and 0 } \\
\text { otherwise. }\end{array}$ \\
\hline
\end{tabular}

\subsection{Econometric Issues}

A general concern in the literature dealing with fiscal cyclicality is the possibility of the output cycle being endogenously determined by the fiscal indicator (Gavin and Perotti, 1997; Gali and Perotti, 2003; Lane, 2003; Jaimovich and Panizza, 2007). This potential endogeneity arises mainly for three reasons: (a) the reverse causality between fiscal variable and output (Jaimovich and Panizza, 2007); (b) including the lagged fiscal variable as an independent variable; and (c) due to simultaneity bias in system equations. To overcome the endogeneity issue we have instrumented output with share of manufacturing in total GDP and lagged real GDP. We have assessed the validity of these instruments by performing the Hansen $\mathrm{J}$ test for over-identification. This test suggests that it is appropriate to instrument the GDP cycle with the share of manufacturing output in total GDP and lagged real GDP.

A prerequisite for the estimation of the system of equations is the identification of equations. In every equation the number of exclusions is sufficient for the order condition for identification to be satisfied. The rank condition can safely be assumed to hold in a model of this size. Our individual equations and hence the whole system is supposed to be overidentified. Therefore, to estimate this over-identified system and to tackle the simultaneity problem, we will apply a reliable instrumental variable estimation technique like the Generalized Method of Moments (GMM) to estimate our model. 


\section{DATA OVERVIEW, ESTIMATION AND DISCUSSION OF RESULTS}

\subsection{Data Overview}

This section presents some descriptive statistics of the variables. Table 3 provides the descriptive statistics of the fiscal variables and their potential determinants. In general, we find that government expenditures are higher than government revenues, as a result SACs suffer from a deteriorating fiscal balance position. Real GDP shows the highest fluctuations as the high value of standard deviation (247.53) indicates, because SACs comprise both small countries like the Maldives with low GDP and large countries like India with a somewhat high GDP in the region. High real GDP fluctuations are followed by terms of trade shocks. Not surprisingly, SACs are not highly integrated into the international financial markets and they do not even have deeper domestic credit markets. Finally, SACs have less democratic regimes and weaker institutions.

Table 4 displays the correlations between the fiscal variables and its determinants. The correlation analysis shows that: (a) the increase in the business cycle is procyclical in South Asian countries as it increases expenditures and reduces government revenues, thereby worsening the fiscal balance; (b) improvement in terms of trade shock is counter cyclical as it exhibits an improvement in both government revenues and fiscal balance; (c) inflation has a procyclical effect on fiscal balance as the procyclical effect of inflation on expenditures is greater than its counter cyclical effects on revenues; (d) wider access to domestic private credit (financial depth) and international capital market (financial openness) are procyclical in SACs as they display lower (higher) levels of government revenues (expenditure) and hence deteriorating government balance position; (e) more power dispersion (i.e. higher values of polity) is negatively correlated with total revenue and positively correlated with expenditure, and hence shows a negative degree of association with the budget balance, as the increase in expenditure is greater than the increase in revenues, so democracy is procyclical in SACs, (f) stronger institutions have a negative association with revenue and expenditure but have nothing to do with fiscal balance; and (g) SACs followed the policy of counter cyclical after the event of $9 / 11$ as the dummy is positively (negatively) correlated with government revenues (expenditures) and fiscal balance. We interpret these high simple correlations between variables as validating our selection of variables. 
Table 3

Descriptive Statistics of the Variables

\begin{tabular}{lcccccc}
\hline & Mean & Median & Maximum & Minimum & $\begin{array}{c}\text { Std. } \\
\text { Dev. }\end{array}$ & Obs. \\
\hline Revenues (\% of GDP) & 17.27 & 15.95 & 42.60 & 8.30 & 7.26 & 238 \\
Expenditures (\% of GDP) & 25.52 & 21.80 & 70.20 & 11.30 & 11.40 & 238 \\
Fiscal Balance (\% of GDP) & -8.20 & -6.40 & 5.40 & -40.10 & 7.06 & 238 \\
Real GDP & & & & & & \\
(constant 2005 US\$) & 108.66 & 16.85 & 1381.30 & 0.10 & 247.53 & 238 \\
Terms of Trade Index & 114.10 & 108.45 & 319.60 & 38.20 & 41.06 & 238 \\
Inflation (\%) & 8.26 & 8.30 & 22.60 & -1.70 & 4.05 & 238 \\
Financial Depth (private & & & & & & \\
sector credit \% of GDP) & 24.32 & 23.40 & 69.30 & 2.50 & 13.54 & 238 \\
Financial Openness Index & -0.68 & -1.20 & 2.40 & -1.90 & 1.08 & 238 \\
Democracy & 1.73 & 5.00 & 9.00 & -10.00 & 6.60 & 204 \\
Institutional Quality & 48.96 & 49.63 & 65.50 & 28.58 & 9.43 & 136 \\
\hline
\end{tabular}

Table 4

Correlation Matrix of the Variables

\begin{tabular}{lccc}
\hline & $\begin{array}{c}\text { Revenues } \\
\text { (\% of GDP) }\end{array}$ & $\begin{array}{c}\text { Expenditures }(\% \text { of } \\
\text { GDP) }\end{array}$ & $\begin{array}{c}\text { Fiscal Balance } \\
\text { (\% of GDP) }\end{array}$ \\
\hline Real Output & -0.56 & 0.38 & -0.09 \\
Terms of Trade & $(-7.77)^{*}$ & $(4.72)^{*}$ & $(-1.01)$ \\
Inflation & 0.27 & 0.02 & 0.22 \\
& $(3.24)^{*}$ & $(0.22)$ & $(2.53)^{*}$ \\
Financial Depth & 0.31 & 0.35 & -0.29 \\
Financial Openness & $(3.69)^{*}$ & $(4.27)^{*}$ & $(-3.45)^{*}$ \\
& -0.49 & -0.24 & -0.07 \\
Democracy & $(-6.48)^{*}$ & $(-2.82)^{*}$ & $(-0.80)$ \\
& -0.22 & 0.38 & -0.42 \\
Institutional Quality & $(-2.52)^{*}$ & $(4.70)^{*}$ & $(-5.21)^{*}$ \\
& -0.22 & 0.04 & -0.28 \\
Dummy & $(-2.55)^{*}$ & $(0.40)$ & $(-3.38)^{*}$ \\
& -0.49 & -0.24 & -0.08 \\
& $(-6.47)^{*}$ & $(-2.79)^{*}$ & $(-0.87)$ \\
& 0.51 & -0.30 & 0.03 \\
& $(6.80)^{*}$ & $(-3.55)^{*}$ & $(0.35)$ \\
\hline
\end{tabular}

Note: * significant at $5 \%$ level.

Figure 2 presents a scatter diagram between output growth and fiscal balance. It indicates an inverse relationship between the two variables, that is, as output growth increases, fiscal balance will deteriorate in SACs. Taken 
at face value, both the simple correlations and scatter diagram suggest that fiscal policy is procyclical in SACs. It is of course necessary to control for other factors while focusing on any particular factor, e.g. real output. Furthermore, the picture that emerges may be different when we turn to conditional statements based on multiple regressions and control for the potential endogeneity bias.

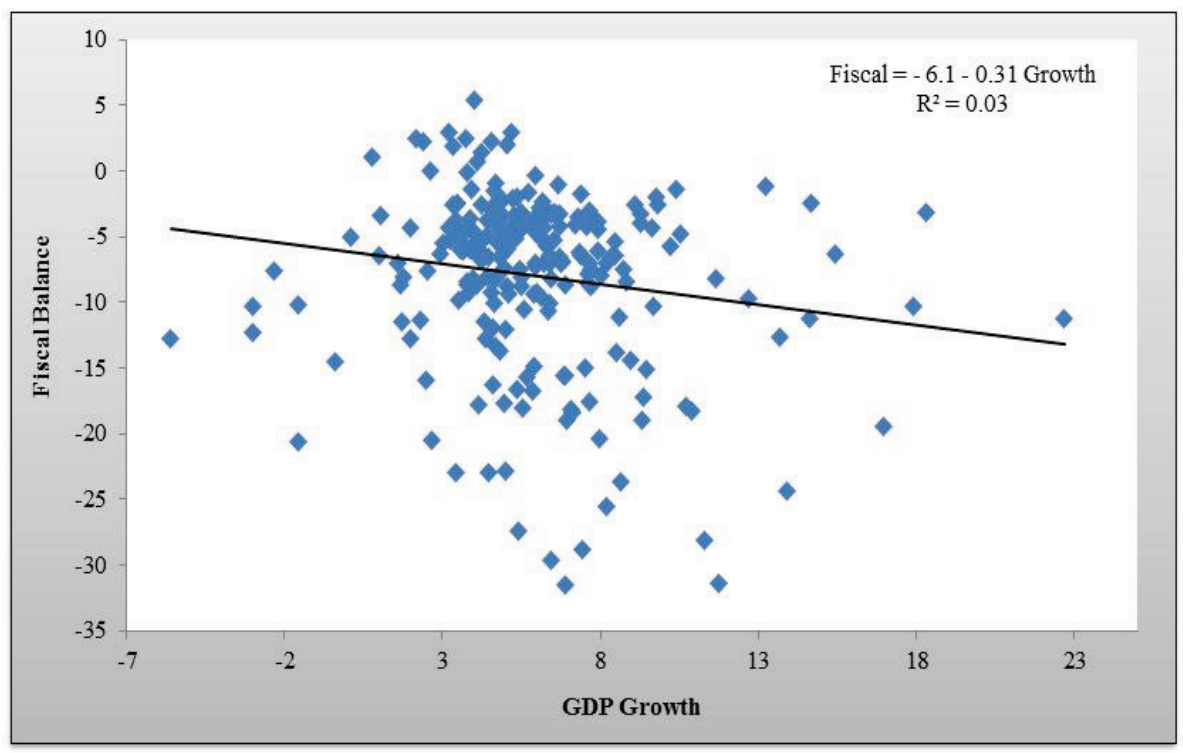

Figure 2. Scatter Diagram between Fiscal Balance and GDP Growth

\subsection{Estimation and Discussion of Results}

The model is estimated using the dynamic system GMM estimation technique. Manufacturing production and lagged real GDP are used as instruments for real GDP to resolve the endogeneity issue. Separate instruments are used for each equation. Initially we included a number of variables in the model. However, we have excluded all those variables from our system specification that appeared insignificant in repeated estimations. This exercise has helped us to get a model in which our results are not sensitive to model specifications. Table 5 provides the estimated results. The explanatory power of each equation of our structural model is quite high, as indicated by the high values of R-squared and adjusted R-squared. The values of the Durbin-Watson (DW) statistics are reasonably close to the 
desired value of two in almost all equations, which indicates the absence of autocorrelation problem from the model. Moreover, the absolute values of the Durbin $h$-test are less than |1.96|, which again indicates the absence of autocorrelation problem from the models. The high $\mathrm{p}$-value of J-statistics (1.000) indicates that the instruments used are valid. The interpretation of each variable is explained below one by one.

Output Cycles: For the South Asia region as a whole, the results align with the empirical literature that fiscal policies are highly procyclical. The coefficient estimate of government revenue is negative and significant and the coefficient estimate of government expenditures is positive and significant, thus indicating a procyclical fiscal policy in the region. This reflects the fact that output expansion would be associated with a decrease in government revenue and an increase in government expenditure. This result shows that output expansions decrease the fiscal balance. Speaking in economic terms, the results suggest that a one standard deviation increase in output (247.53) would decrease fiscal balance by 0.56 percent of GDP. Statistically speaking, fiscal balance is acyclical in models (1) and (2), that is, it is not statistically significant in these models. But it is procyclical in model (3) as it is statistically significant in this model.

The business cycle coefficients without control variables would be biased upward. However, estimating the coefficients without control variables allow us to explain fiscal procyclicality by the control variables. Therefore we have also explored the factors driving the cyclicality of fiscal variables. The table also reports the results of the regression of six sets of variables that have been shown in the literature to influence the cyclicality of fiscal policy: external shocks, fiscal space, financing constraints, political and institutional factors, and structural change.

External (Terms-of-Trade) Shocks: In our analysis it is found that revenues show significant positive response to (favourable) terms of trade shocks. So revenues are consistent with counter-cyclical fiscal policy. It is also found that public expenditures are heightened by terms-of-trade shocks, which shows a procyclical fiscal policy. Curiously, it is hence expected that frequent and large terms-of-trade shocks would spur fiscal profligacy in SACs. The significant negative coefficient on budget balance indicates that budget balance decreases with (favourable) terms-of-trade shocks in SACs. Hence, an increase in the terms of trade by one standard deviation (i.e. 41.06) decreases fiscal balance by 0.25 percent of GDP in SACs. Overall, our findings are consistent with procyclical fiscal policies.

Inflation: Inflation, which is used to measure fiscal space, has a significant effect on the cyclicality of the fiscal variables. It has a counter 
cyclical effect on government revenues as it increases (nominal) revenues, while it has a procyclical effect on government spending. Quantitatively, the effect of inflation is greater on spending than on revenues. Thus, inflation has a procyclical effect on fiscal balance and this effect is statistically significant.

Financing Constraints: To gauge the effect of financial constraints on fiscal variables, two variables - financial depth and financial openness - are included. The former variable captures the effect of domestic financial development while the latter variable takes into account the effect of integration into international capital market. Theoretically, it is presumed that the countries with wider access to domestic and/or world capital markets may be able to run counter cyclical fiscal policies. Contrary to theoretical arguments, our empirical results indicate that fiscal policies in SACs are procyclical. As access to both domestic financial markets (financial depth) and international capital markets (financial openness) have decreased (increased) government revenues (expenditures), hence they have deteriorated government fiscal balance. The coefficient on financial depth is statistically negative (positive) for revenues (expenditures) and fiscal balance. Similarly, the coefficient on financial openness is statistically negative (positive) for revenues (expenditures) and fiscal balance. Interestingly, these findings for SACs are not consistent with the borrowing constraints premise that fiscal policies in developing countries are to be counter cyclical during expansions as argued by Alesina et al. (2008).

One reason for these procyclical fiscal policies is that in SACs, financial markets are shallow with credit below 25 percent of GDP. Fiscal policies may become counter cyclical as financial development deepens (Calderon and Schmidt-Hebbel, 2008). Similarly, SACs have a very low degree of financial openness $(-0.68)$ which is why fiscal policies are procyclical in these countries. In contrast, if these countries become more financially open, they may tend to show counter cyclical fiscal policies (Calderon and Schmidt-Hebbel, 2008). Furthermore, high dependency on foreign capital heightens fiscal procyclicality because it is viewed as volatile, unpredictable, and overwhelmingly procyclical in many recipient countries (Pallage and Robe, 2001; Bulir and Hamann, 2008). Moreover, it is often found that disbursements of foreign capital in SACs increase during expansion episodes and stop suddenly in downturns, and during political instability. This leads to slow economic growth which results in procyclical fiscal policies in SACs. 
Table 5

Cyclicality of Revenues, Expenditures and Fiscal Balance: Empirical Estimates

\begin{tabular}{|c|c|c|c|c|c|c|c|c|c|}
\hline & \multicolumn{3}{|c|}{ Model 1} & \multicolumn{3}{|c|}{ Model 2} & \multicolumn{3}{|c|}{ Model 3} \\
\hline & Revenues & Expenditures & Fiscal Balance & Revenues & Expenditures & Fiscal Balance & Revenues & Expenditures & Fiscal Balance \\
\hline \multirow[t]{2}{*}{ Intercept } & 0.499 & 0.222 & 0.277 & 1.460 & 0.958 & 0.502 & 4.344 & 3.977 & 0.367 \\
\hline & $(7.344)^{*}$ & $(2.363)^{*}$ & $(3.403)^{*}$ & $(11.481)^{*}$ & $(6.050)^{*}$ & $(3.109)^{*}$ & $(30.050)^{*}$ & $(23.418)^{*}$ & $(2.072)^{*}$ \\
\hline \multirow[t]{2}{*}{ Real Output } & -0.001 & 0.001 & -0.002 & -0.001 & 0.001 & -0.002 & -0.001 & 0.001 & -0.002 \\
\hline & $(-24.246)^{*}$ & $(21.331)^{*}$ & $(-0.134)$ & $(-11.867)^{*}$ & $(12.714)^{*}$ & $(-0.580)$ & $(-20.631)^{*}$ & $(14.576)^{*}$ & $(-2.748)^{*}$ \\
\hline \multirow[t]{2}{*}{ External Shock } & 0.011 & 0.017 & -0.006 & 0.013 & 0.016 & -0.003 & 0.005 & 0.014 & -0.009 \\
\hline & $(22.256)^{*}$ & $(21.173)^{*}$ & $(-9.198)^{*}$ & $(20.700)^{*}$ & $(14.164)^{*}$ & $(-3.158)^{*}$ & $(9.450)^{*}$ & $(1.580)$ & $(-3.772)^{*}$ \\
\hline \multirow[t]{2}{*}{ Inflation } & & & & 0.010 & 0.073 & -0.063 & 0.023 & 0.032 & -0.008 \\
\hline & & & & $(8.400)^{*}$ & $(4.789)^{*}$ & $(-2.299)^{*}$ & $(3.571)^{*}$ & $(1.679)^{* *}$ & $(-6.880)^{*}$ \\
\hline \multirow[t]{2}{*}{ Financial Depth } & & & & -0.018 & 0.006 & -0.025 & -0.035 & 0.071 & -0.106 \\
\hline & & & & $(-6.566)^{*}$ & $(2.032)^{*}$ & $(-4.701)^{*}$ & $(-24.167)^{*}$ & $(25.833)^{*}$ & $(-13.422)^{*}$ \\
\hline \multirow[t]{2}{*}{ Financial Openness } & & & & -0.692 & 0.553 & -1.245 & -0.160 & 0.563 & -0.723 \\
\hline & & & & $(-20.489)^{*}$ & $(14.637)^{*}$ & $(-3.718)^{*}$ & $(-9.269)^{*}$ & $(27.614)^{*}$ & $(-15.949)^{*}$ \\
\hline \multirow[t]{2}{*}{ Democracy } & & & & & & & 0.004 & 0.032 & -0.028 \\
\hline & & & & & & & $(1.739)^{* *}$ & $(7.869)^{*}$ & $(-9.072)^{*}$ \\
\hline \multirow[t]{2}{*}{ Institutional Quality } & & & & & & & -0.037 & -0.049 & 0.012 \\
\hline & & & & & & & $(-24.545)^{*}$ & $(-22.790)^{*}$ & $(5.150)^{*}$ \\
\hline \multirow[t]{2}{*}{ Dummy } & 0.292 & 0.238 & 0.054 & 0.439 & 0.230 & 0.209 & 0.954 & 0.587 & 0.367 \\
\hline & $(6.458)^{*}$ & $(6.582)^{*}$ & $(1.643)^{* *}$ & $(6.702)^{*}$ & $(2.962)^{*}$ & $(4.063)^{*}$ & $(18.636)^{*}$ & $(16.707)^{*}$ & $(6.875)^{*}$ \\
\hline \multirow[t]{2}{*}{ Revenue, Lag } & 0.900 & & 0.900 & 0.835 & & 0.835 & 0.824 & & 0.824 \\
\hline & (294.269)* & & $(294.269)^{*}$ & $(161.164)^{*}$ & & (161.164)* & (111.021)* & & $(111.021)^{*}$ \\
\hline \multirow[t]{2}{*}{ Expenditure, Lag } & & 0.908 & -0.908 & & 0.883 & -0.883 & & 0.880 & -0.880 \\
\hline & & $(391.910)^{*}$ & $(-391.910)^{*}$ & & $(215.432)^{*}$ & $(-215.432)^{*}$ & & $(302.708)^{*}$ & $(-302.708)^{*}$ \\
\hline No. of Countries & 7 & 7 & 7 & 7 & 7 & 7 & 4 & 4 & 4 \\
\hline Obs. & 210 & 210 & 210 & 210 & 210 & 210 & 124 & 124 & 124 \\
\hline R-squared & 0.918 & 0.912 & 0.763 & 0.920 & 0.911 & 0.768 & 0.882 & 0.948 & 0.831 \\
\hline Adjusted R-squared & 0.916 & 0.910 & 0.752 & 0.917 & 0.908 & 0.750 & 0.873 & 0.944 & 0.801 \\
\hline S.E. of regression & 2.153 & 3.498 & 3.391 & 2.145 & 3.534 & 3.406 & 1.268 & 1.413 & 1.594 \\
\hline Durbin-Watson stat & 1.877 & 1.994 & 2.386 & 1.810 & 1.989 & 2.338 & 2.043 & 1.900 & 2.390 \\
\hline Durbin $|h|$ stat & 0.890 & 0.041 & - & 1.381 & 0.078 & - & 0.239 & 0.559 & - \\
\hline J-statistics & 0.023 & & & 0.029 & & & 0.215 & & \\
\hline Prob. (J-statistics) & $(1.000)$ & & & $(1.000)$ & & & $(1.000)$ & & \\
\hline
\end{tabular}

Note: Numbers in parentheses are t—values; ${ }^{*}(*)$ significant at $5 \%(10 \%)$ level. 
Political and Institutional Factors: Theoretically, it is assumed that countries with a strong political system and good quality institutions may be able to run countercyclical fiscal policies. In estimated results, revenues show a counter cyclical pattern with democracy as democracy is found to positively affect revenues. However, the coefficient on democracy is marginally statistically significant at 10 percent level. In turn, democracy has a procyclical effect on government expenditure as the coefficient on democracy is positive and statistically significant. Quantitatively, the effect of democracy on expenditure dominates more than its effect on revenue, it is therefore expected that it will deteriorate the fiscal balance. Significant negative coefficient on democracy indicates that the fiscal balance is procyclical in SACs. Speaking in economic terms, one standard deviation increase in democracy (6.60) will diminish fiscal balance by 0.18 percent of GDP. In our data set, democracy shows procyclical rather than counter cyclical behaviour in SACs. This result is consistent with the notion that SACs do have multiple players intervening in the fiscal process as democratic regimes are associated with more power dispersion. This finding is consistent with theories that explain that political distortions and voracity effects hold in more democratic regimes.

It is anticipated that the quality of institutions would increase revenue and dampen profligacy. Empirical results exhibit that the coefficient of institutional quality appears with negative signs both in revenues and expenditures i.e. institutional quality significantly negatively affects both revenues and expenditures. This indicates that government revenues display procyclical behaviour, while government expenditure exhibits a counter cyclical pattern in SACs as institutional quality improves. As a result, government fiscal balance is countercyclical in SACs with stronger institutions. That is, fiscal balance improves in SACs when their institutional quality improves. In economic terms, a one standard deviation improvement in institutional quality (9.43) would increase fiscal balance by 0.11 percent of GDP. All this indicates that the quality of institutions play an important and quantitatively significant role in controlling total government expenditure and improving fiscal balance in SACs.

Structural Change: We introduce a dummy variable to capture the effect of the $9 / 11$ event with a value of 1 in the post 9/11 period. The dummy variable is positive and statistically significant in each and every equation of Table 5. It indicates that government revenues are counter cyclical while government expenditures are procyclical. This finding is not consistent with the suggestions that after 9/11 public spending has tended to be counter cyclical across the SACs. Quantitatively, the effect of the dummy is greater 
on revenues than on expenditures, therefore it is expected that government fiscal balance would be counter cyclical. The statistically significant positive coefficient on the dummy in the fiscal balance equation confirms this proposition. In economic terms, after the event of 9/11 the fiscal balance has improved by 0.367 percent of GDP in SACs. The main reason is that these countries have received enormous remittances from expatriates as emigrants feel insecure to put their money in foreign banks. Furthermore, these countries - especially Pakistan - have received a massive amount of foreign aid working as front line states against terrorism.

Lag Fiscal: Finally, our models include the lagged dependent variable as an independent variable to check persistency in the fiscal variables. Consistent with most of the empirical literature, the inertia effect captured by the coefficient on the lagged fiscal policy variable is positive both for revenues and expenditures and they are highly statistically significant. This suggests a high degree of persistence in fiscal policy. Since current fiscal performance is strongly determined by the previous year, it suggests that exogenous shocks, in the absence of automatic stabilizers, would result in procyclical fiscal policies across the region. ${ }^{3}$ But the effect of inertia could disappear over time which is implied by the absolute value of the estimated coefficient of less than 1. Taken together, the empirical results provide considerable support for macroeconomic, political and institutional factors in determining variation in fiscal cyclicality in SACs.

\subsection{Sensitivity Analysis}

\subsubsection{Inclusion of Interaction Terms}

To further check the role of financial openness and the political system on the cyclicality of fiscal policy we have included the interaction terms between real GDP and international financial integration and between real GDP and democracy. Table 6 provides the estimated results. The interaction term between real GDP and access to international financial markets is negative (positive) and significant for government revenues (expenditures) and fiscal balance. This indicates that even relaxing credit constraints may give SACs the fiscal space to run procyclical fiscal policies. This result

\footnotetext{
${ }^{3}$ We also estimated the results without the lagged dependent variable to assess the extent of the possible correlation with the error component. The results remained qualitatively robust in these different specifications and we report on those including the lagged dependent variable, to address the notion of fiscal sustainability (or more correctly, inertia).
} 
confirms our previous findings that financial openness is procyclical in SACs as these countries have a lower degree of international capital openness. The interaction term between real GDP and democracy (voracity effect) is positive and significant both for government revenue and expenditure, however it is negative and significant for government fiscal balance. This again verifies our previous results that a rise in democracy (i.e. a wider dispersion of power) lead to procyclicality in the fiscal balance in SACs. These results support the existing theories that argue that procyclical fiscal policies occur due to the voracity effect. This result suggests that SACs may be able to pursue counter cyclical policies if they do not have multiple players affecting the fiscal procedures. Thus the findings again suggest that procyclical bias in SACs occurs due to political distortions and voracity effects.

The coefficient of real output is negative (positive) and significant for revenues (expenditures) and fiscal balance, thus indicating that government revenue, expenditure and fiscal balance are procyclical in SACs. External shock positively affects both revenues and expenditures and its influence on fiscal balance are negative and significant. Thus both real output and external shocks affect fiscal balance procyclically. The structural dummy affects both revenues and fiscal balance counter cyclically while it affects expenditures procyclically. All these results are consistent with our prior findings.

\subsubsection{Good and Bad Times}

To seek the effect of good (and bad) times on the cyclicality of the fiscal variables a dummy variable for good times is introduced which takes the value of 1 for good times and zero otherwise. 'Good time' is defined as a period during which the absolute value of real output gap is below the mean absolute value of real output gap. ${ }^{4}$ The empirical estimates, presented in Table 6, indicate that the coefficient on the good times dummy is significant and negative (positive) for government revenues (expenditures) and fiscal balance. This indicates that during good times the degree of procyclicality tends to increase in SACs. This finding is consistent with the theory that governments in developing economies ease their fiscal policies and spend more during a boom period.

\footnotetext{
${ }^{4}$ Output gap is the percentage difference between the actual and potential real GDP. Potential real GDP is calculated using the HP filter technique.
} 
Table 6

Cyclicality of the Fiscal Variables with the Inclusion of Interaction Terms and Time Effect

\begin{tabular}{|c|c|c|c|}
\hline & Revenues & Expenditures & Fiscal Balance \\
\hline Intercept & $\begin{array}{l}2.520 \\
(25.706)^{*}\end{array}$ & $\begin{array}{l}1.847 \\
(14.622)^{*}\end{array}$ & $\begin{array}{l}0.674 \\
(4.770)^{*}\end{array}$ \\
\hline Real Output & $\begin{array}{l}-0.010 \\
(-10.380)^{*}\end{array}$ & $\begin{array}{l}0.009 \\
(6.644)^{*}\end{array}$ & $\begin{array}{l}-0.019 \\
(-14.258)^{*}\end{array}$ \\
\hline External Shock & $\begin{array}{l}0.006 \\
(13.435)^{*}\end{array}$ & $\begin{array}{l}0.003 \\
(3.675)^{*}\end{array}$ & $\begin{array}{l}-0.003 \\
(-5.001)^{*}\end{array}$ \\
\hline Real Output * Financial Openness & $\begin{array}{l}-0.006 \\
(-8.943)^{*}\end{array}$ & $\begin{array}{l}0.010 \\
(11.302)^{*}\end{array}$ & $\begin{array}{l}-0.016 \\
(-17.335)^{*}\end{array}$ \\
\hline Real Output * Democracy & $\begin{array}{l}0.002 \\
(8.585)^{*}\end{array}$ & $\begin{array}{l}0.003 \\
(8.492)^{*}\end{array}$ & $\begin{array}{l}-0.001 \\
(-2.859)^{*}\end{array}$ \\
\hline Good Time & $\begin{array}{l}0.079 \\
(2.196)^{*}\end{array}$ & $\begin{array}{l}0.807 \\
(19.505)^{*}\end{array}$ & $\begin{array}{l}-0.728 \\
(-15.872)^{*}\end{array}$ \\
\hline Dummy & $\begin{array}{l}0.333 \\
(9.549)^{*}\end{array}$ & $\begin{array}{l}0.087 \\
(3.730)^{*}\end{array}$ & $\begin{array}{l}0.245 \\
(8.563)^{*}\end{array}$ \\
\hline Revenue, Lag & $\begin{array}{l}0.890 \\
(310.955)^{*}\end{array}$ & & $\begin{array}{l}0.890 \\
(310.955)^{*}\end{array}$ \\
\hline Expenditure, Lag & & $\begin{array}{l}0.903 \\
(408.848)^{*}\end{array}$ & $\begin{array}{l}-0.903 \\
(-408.848)^{*}\end{array}$ \\
\hline No. of Countries & 4 & 4 & 4 \\
\hline Obs. & 124 & 124 & 124 \\
\hline $\mathrm{R}$-squared & 0.881 & 0.943 & 0.818 \\
\hline Adjusted R-squared & 0.874 & 0.939 & 0.793 \\
\hline S.E. of regression & 1.266 & 1.476 & 1.625 \\
\hline Durbin-Watson stat & 2.129 & 1.960 & 2.389 \\
\hline Durbin $|h|$ stat & 0.719 & 0.223 & - \\
\hline $\begin{array}{l}\text { J-statistics } \\
\text { Prob. (J-statistics })\end{array}$ & $\begin{array}{l}0.187 \\
(1.000)\end{array}$ & & \\
\hline
\end{tabular}

\subsubsection{Output Volatility}

We have also examined the robustness of our results by applying the output volatility alternative to real output to assess the effect of output on fiscal cyclicality. Output volatility is proxied by the output gap. ${ }^{5}$ Figure 3

\footnotetext{
${ }^{5}$ Technically speaking, output gap shows the deviation of real GDP from its long-term trend and since volatility is a measure of variation of a variable over time, we can use output gap as a proxy measure of output volatility. For details, see Bogdanov (2010).
} 
provides a scatter diagram between output volatility and government revenues which clearly presents a negative relationship between output volatility and government revenues. Similarly, the scatter diagram in Figure 4 shows that there is a positive relationship between output volatility and government expenditures. Finally, the scatter diagram in Figure 5 plots the relationship between output volatility and fiscal balance, which is basically negative. The estimated results are provided in Table 7. Just like real output, real output volatility has a significant positive effect on government expenditure, while it has a significant negative effect on both government revenue and fiscal balance. All this indicates that output volatility is procyclical in SACs. All the other results are also retained. External shocks have procyclical effects on government fiscal balance while the structural dummy has a counter cyclical impact on fiscal balance. In fact, HP-filtered data (output volatility) deliver very similar results. This result confirms Lane's (2003) view that it does not make any difference if actual output is used or the difference between actual and potential output is used.

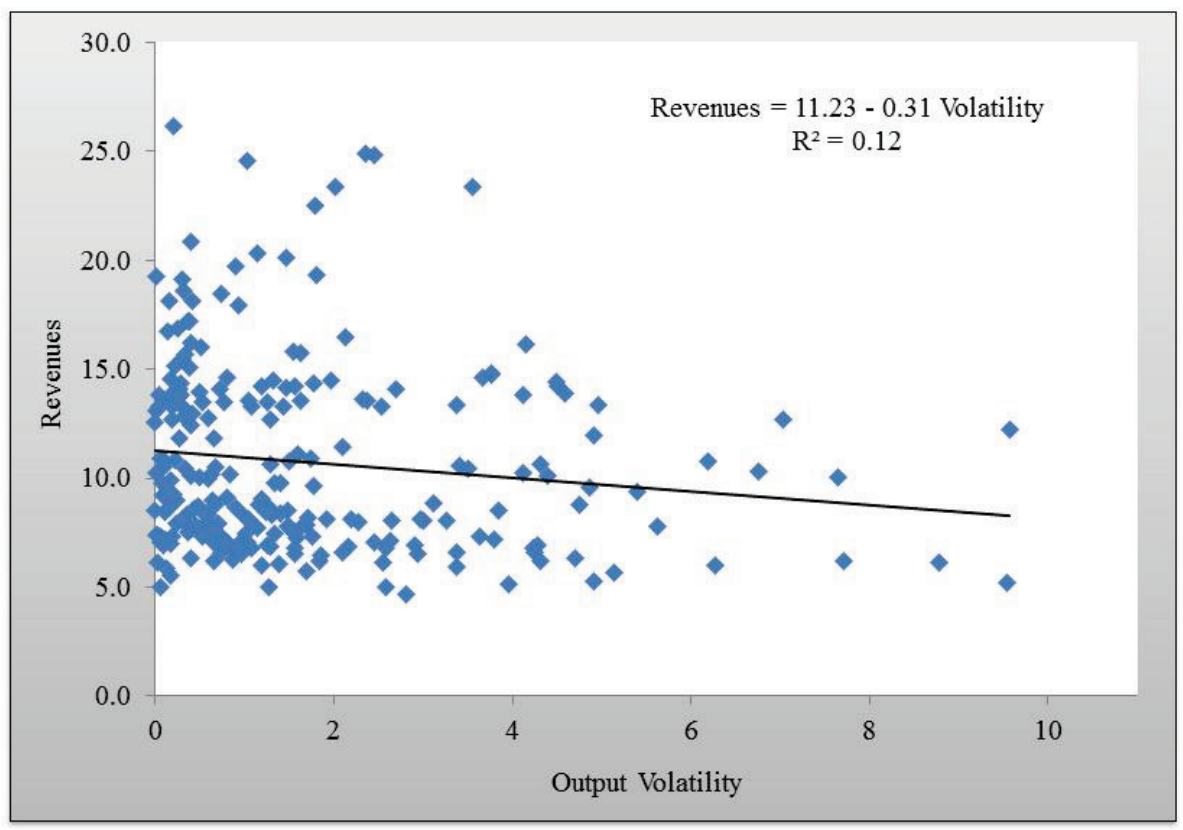

Figure 3. Scatter Diagram between Output Volatility and Revenues 


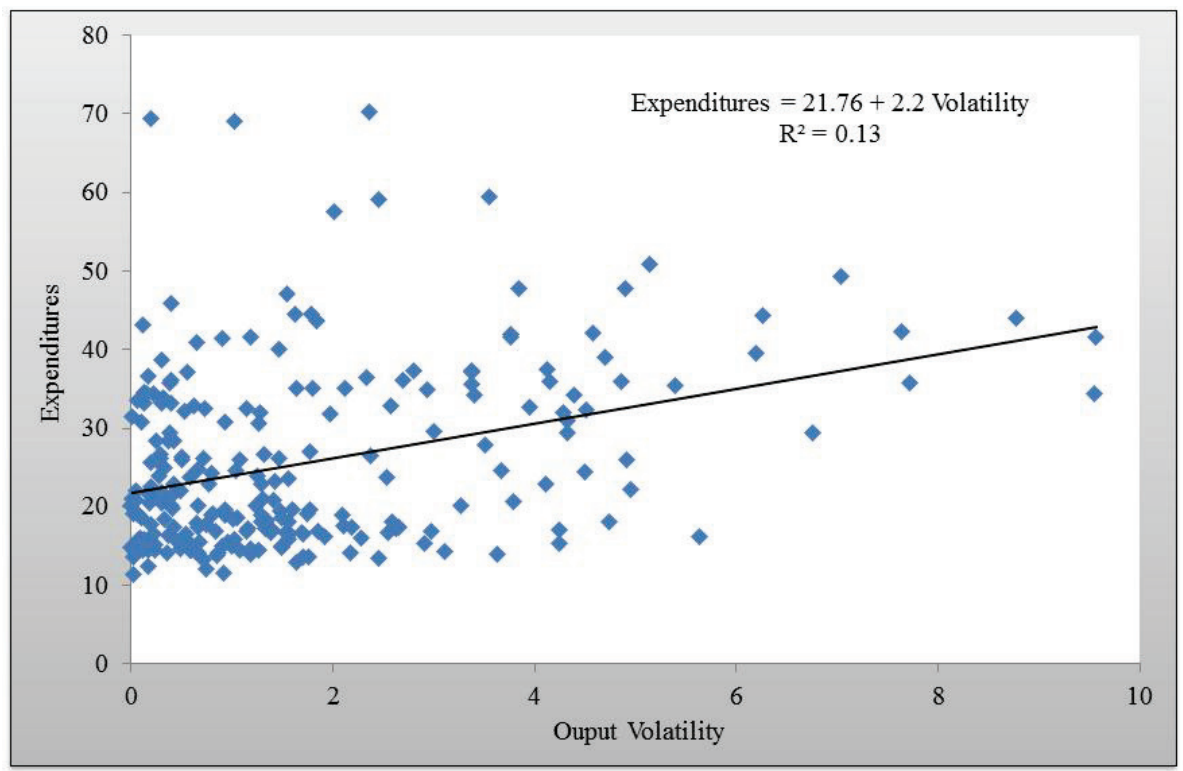

Figure 4. Scatter Diagram between Output Volatility and Expenditures

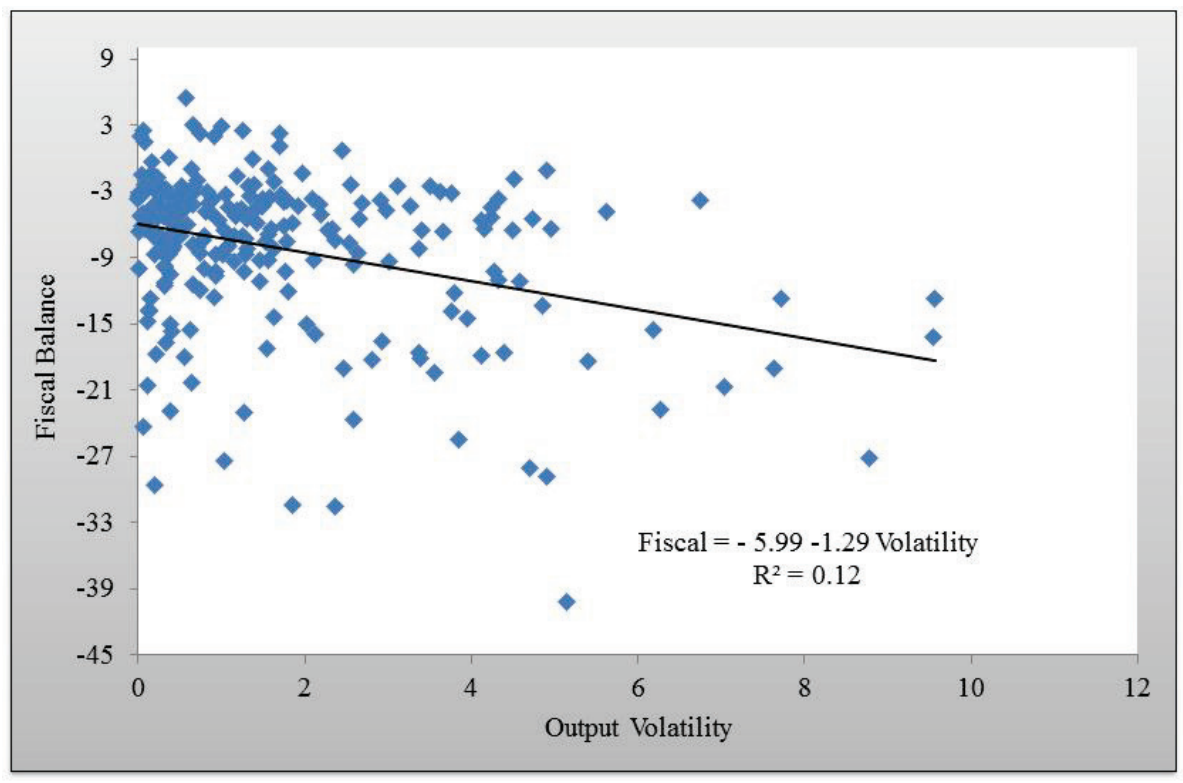

Figure 5. Scatter Diagram between Output Volatility and Fiscal Balance 


\section{CONCLUSION}

The paper empirically examines the behaviour of fiscal policies in SACs over the business cycle for the period 1980 to 2013. Structural panel regression analysis is conducted for three fiscal policy indicators i.e. revenues, expenditures and fiscal policies for seven SACs. The empirical analysis confirms the results of previous studies addressing the behaviour of government fiscal policies in developing countries. The panel data for the seven South Asian countries - Bangladesh, Bhutan, India, Maldives, Nepal, Pakistan, and Sri Lanka - provide strong evidence of procyclicality. Budget balances are procyclical in SACs with business as these are developing countries and they are driven by the procyclical behaviour of government revenues and expenditure. Thisprocyclicality escalates during good times and this procyclicality even holds when the output cycle is measured by output volatility instead of real GDP. Inflation (fiscal space) and external (terms of trade) shocks also have significant procyclical effects on fiscal balances.

We also find that low (not wide) levels of access to domestic and international credits are statistically significant drivers of procyclicality in the region. The analysis further shows that a weak political system (i.e. wider dispersion of power) also explains the procyclicality of fiscal policies in SACs. These results confirm the theoretical arguments that political distortions and structural market failures may be responsible for the procyclical bias of fiscal policies in South Asia. In contrast, SACs are able to conduct counter cyclical fiscal balance policies with high levels of institutional quality and the structural event of $9 / 11$. They help provide a counter balancing influence in attenuating, but not totally eliminating, the procyclical bias. Finally, the coefficients on the lagged dependent variable are positive, implying a persistency in revenue and spending policies which could have adverse consequences for the accumulation of public debt. Thus, our estimated results generally support the notions that macroeconomic, political economy and institutional factors play a key role in determining the cyclicality of fiscal policies in SACs. These results are not sensitive to alternative model specifications and business cycle measures.

The paper has some policy implications. The tendency to use revenue to boost spending may not be appropriate during good times or spending windfall commodity export receipts as their prices rise. This ramped up spending can easily be of poor quality and wasted, with adverse implications for building the physical and human capital needed to generate long-term wealth in a region endowed with considerable natural resources but relatively high poverty. This may also exacerbate economic volatility and 
hence hinder growth. The fiscal expansion must be well-timed as mistimed interventions can be counter-productive. This requires strong fiscal institutions to design and implement any proposed spending increase and improvement in data quality to identify the ups and downs in real-time business cycles.

The results suggest that SACs are more likely to conduct optimal fiscal policy if they have deeper domestic financial markets, high integration with the world credit market, lesser power dispersion and a stronger institutional framework. For that to happen, SACs may develop their domestic financial market and integrate their economies into world financial markets. SACs need to further improve their institutional framework in which fiscal policy operates, through more effective budgetary management and transparency, and eventually via fiscal rules, which so far are not being widely used in the region.

This study could be extended in a number of directions. Models may be developed to incorporate the possible role played by international financial crises in inducing fiscal procyclicality in SACs. A study may be conducted that could consider some other fiscal policy indicators, for example tax rates, capital expenditures, investment spending, etc. A further study could explore the possible channels or transmission mechanisms through which financial integration and institutions are expected to affect the cyclicality of fiscal policy in SACs.

\section{REFERENCES}

Alesina, A., F. R., Campante, G., Tabellini, Why is Fiscal Policy Often Procyclical?, "Journal of the European Economic Association”, 6(5), pp.1006-1036, 2008.

Badinger, H., Cyclical Fiscal Policy, Output Volatility, and Economic Growth, "Working Paper" No. 2268, CESifo, 2008.

Barro, R. J.,On the Determination of the Public Debt, "Journal of Political Economy", 87, pp. 940-971, 1979.

Baxter, M., R. G., King, Fiscal Policy in General Equilibrium, "American Economic Review", 83, pp. 315-334, 1993.

Bogdanov, B., Cyclicality of Fiscal Policy over the Business Cycle: An Empirical Study on Developed and Developing Countries, Working Paper No. 1, Agency for Economic Analysis and Forecasting, Sofia, 2010.

Braun, M., Why is Fiscal Policy Procyclical in Developing Countries?, CIPPEC, Manuscript, May 2001.

Buiter, W. H. (1999), The Fallacy of the Fiscal Theory of the Price Level, Working Paper No. 7302, NBER 
Bulir, A., Hamann, A., Volatility of Development Aid: From the Frying Pan into the Fire?, "World Development", 36(10), pp. 2048-2066, 2008.

Caballero, R., Krishnamurthy, A., Fiscal Policy and Financial Depth, Working Paper No. 10532, NBER, 2004.

Calderon, C., Schmidt-Hebbel, K., Business Cycles and Fiscal Policies: The Role of Institutions and Financial Markets, Working Paper No. 481, Central Bank of Chile, 2008.

Catao, L. A., Sutton, W., B., Sovereign Defaults: The Role of Volatility, Working Paper No. 149, IMF, 2002.

Chinn, M., Ito, H., A New Measure of Financial Openness, "Journal of Comparative Policy Analysis", 10(3), pp. 309-22, 2008.

Christiano, L., Eichenbaum, M., Rebelo, S., When is the Government Spending Multiplier Large?, "Journal of Political Economy", 119, pp. 78-121, 2011.

Endegnanew, Y., The Cyclicality of Fiscal Policy in Good and Bad Times, Universitat Autonoma de Barcelona, 2013.

Fatas, A., Mihov, I., Fiscal Policy and Business Cycles: An Empirical Investigation, "Moneda y Credito", 212, pp. 167-210, 2001.

Fiorito, R., Stylized Facts of Government Finance in the G7, Working Paper No.142, IMF, 1997.

Fiorito R., Kollintzas, T., Stylized Facts of Business Cycles in the G7 from a Real Business Cycle Perspective, "European Economic Review", 38(2), pp. 235-269, 1994.

Frankel, J., Vegh, C., Vuletin, G., On Graduation from Fiscal Procyclicality, Working Paper No. 17691, NBER, 2011.

Gali, J., Government Size and Macroeconomic Stability, "European Economic Review", 38(1), pp. 117-132, 1994.

Gali, J., Perotti, R., Fiscal Policy and Monetary Integration in Europe, "Economic Policy", 18(37), pp. 533-572, 2003.

Gavin, M., Perotti, R., Fiscal Policy in Latin America [in:] Bernanke, B., Rotemberg, J. (eds.), NBER Macroeconomics Annual. MIT Press, Cambridge, MA, 1997.

Gavin, M., Hausmann, R. Perotti, R., Talvi, E., Managing Fiscal Policy in Latin America and the Caribbean: Volatility, Procyclicality, and Limited Creditworthiness, Working Paper No. 326, Inter-American Development Bank, 1996.

Hercowitz, Z., Strawczynski, M., Cyclical Ratcheting in Government Spending: Evidence from the OECD, Review of Economics and Statistics, 86, pp. 353-361, 2004.

Hussain, T., Siddiqi, W. M., Fiscal Policy, Institutions and Governance in Selected South Asian Countries, "Pakistan Journal of Commerce and Social Sciences", 7 (2), pp. 331$-345,2013$.

Ilzetzki, E., Vegh, A. C., Procyclical Fiscal Policy in Developing Countries: Truth or Fiction?, NBER Working Paper 14191, Cambridge, MA, 2008.

IMF, Cyclicality of Fiscal Policy and Cyclically Adjusted Fiscal Balances, Working Paper No. 393, IMF, 2005.

Jaimovich, D., Panizza, U., Procyclicality or Reverse Causality, Working Paper No. 599, Inter-American Development Bank, USA, 2007. 
Kaminsky, G., Reinhart, C. Vegh, C., When it Rains it Pours: Procyclical Capital Flows and Macroeconomic Policies [in:] Gertler, M., Rogoff, K., (eds.), NBER Macroeconomic Annual 19, pp.11-82. MIT Press, Cambridge, MA, 2004.

Lane, P. R.,On the Cyclicality of Irish Fiscal Policy, "Economic and Social Review", 29, pp. $1-17,1998$.

Lane, P. R., The Cyclical Behaviour of Fiscal Policy: Evidence from the OECD, "Journal of Public Economics", 87(12), pp. 2661-2675, 2003.

Leeper, E. M., Equilibria under 'Active' and 'Passive' Monetary and Fiscal Policies, "Journal of Monetary Economics", 27(1), pp. 129-147, 1991.

Manasse, P., Procyclical Fiscal Policy: Shocks, Rules, and Institutions - A View from MARS, Working Paper No. 27, IMF, 2006.

Marshall, M. G., Jaggers, K., Polity IV Project: Dataset Users' Manual. Polity IV Project, Arlington, 2009.

Pallage, S., Robe, M., Foreign Aid and the Business Cycle, "Review of International Economics", 9(4), pp. 641-672, 2001.

Stein, E., Talvi, E., Gristani, A., Institutional Arrangements and Fiscal Performance: the Latin American Experience [in:] J.M.Poterba, M., J., Hagen, von J. (eds.), Fiscal Institutions and Fiscal Performance, pp. 103-134. University of Chicago Press, 1999.-

Talvi, E., Vegh, A. C., Tax Base Variability and Procyclical Fiscal Policy in Developing Countries, "Journal of Development Economics", 78(1), pp. 156-190, 2005.

Tornell, A., Lane, P., Voracity and Growth, “American Economic Review”, 89, pp. 22-46, 1999.

Woo, J., Economic, Political and Institutional Determinants of Public Deficits, "Journal of Public Economics", 87, pp. 387-426, 2003.

Woodford, M., Price Level Determinacy Without Control of a Monetary Aggregate, Working Paper No. 5204, NBER, 1995.

Received: April 2014, revised: November 2014 